OPEN ACCESS

Edited by:

Stephen Raverty,

Animal Health Center, Canada

Reviewed by:

Brent Dixon,

Health Canada, Canada

Rajnish Sharma,

Guru Angad Dev Veterinary and Animal Sciences University, India

Alessia Libera Gazzonis,

University of Milan, Italy

*Correspondence:

Josué Díaz-Delgado

josue.diaz101@alu.ulpgc.es;

josue.diazdelgado@tvmdl.tamu.edu

Specialty section:

This article was submitted to

Marine Megafauna,

a section of the journal

Frontiers in Marine Science

Received: 24 December 2019

Accepted: 22 April 2020

Published: 03 June 2020

Citation:

Díaz-Delgado J, Groch KR, Ramos HGC, Colosio AC, Alves BF, Pena HFJ and Catão-Dias JL (2020)

Fatal Systemic Toxoplasmosis by a Novel Non-archetypal Toxoplasma gondii in a Bryde's Whale

(Balaenoptera edeni).

Front. Mar. Sci. 7:336

doi: 10.3389/fmars.2020.00336

\section{Fatal Systemic Toxoplasmosis by a Novel Non-archetypal Toxoplasma gondii in a Bryde's Whale (Balaenoptera edeni)}

\author{
Josué Díaz-Delgado ${ }^{*}$, Kátia R. Groch ${ }^{1}$, Hernani G. C. Ramos ${ }^{2}$, \\ Adriana Castaldo Colosio ${ }^{2}$, Bruna Farias Alves ${ }^{3}$, Hilda F. J. Pena ${ }^{3}$ and \\ José L. Catão-Dias'
}

\footnotetext{
' Laboratory of Wildlife Comparative Pathology, Department of Pathology, School of Veterinary Medicine and Animal Science, University of São Paulo, São Paulo, Brazil, ${ }^{2}$ Instituto Baleia Jubarte, Caravelas, Brazil, ${ }^{3}$ Department of Preventive Veterinary Medicine and Animal Health, School of Veterinary Medicine, University of São Paulo, São Paulo, Brazil
}

Toxoplasma gondii is known to cause sporadic clinical disease and fatality in marine mammals worldwide. It has been recognized primarily in odontocetes, pinnipeds, and mustelids; however, there is very limited information available in mysticetes. We report the results of pathological, immunohistochemical, and molecular genotyping analyses in a Bryde's whale (Balaenoptera edeni) with disseminated toxoplasmosis. A 10.7-mlong, adult, male Bryde's whale in poor body condition was stranded alive on August 21, 2018 in Pontal do Ipiranga, Linhares, Espirito Santo state (Brazil). The animal died shortly after stranding and was promptly autopsied. The main gross findings were diffuse axial skeletal muscle atrophy, generalized congestion, petechiation and ecchymoses, necrotizing splenitis, hepatitis, myocarditis, pneumonia, and lymphadenitis (prescapular, pulmonary, mediastinal, and mesenteric), bilateral scapulohumeral hemarthros, and severe pulmonary edema. A microscopic examination confirmed the aforementioned diagnoses, featuring a histopathologic signature characterized by multisystemic necrotizing inflammation with vasculitis and disseminated intravascular coagulation, thrombosis, and numerous intralesional protozoal cysts and extracellular tachyzoites morphologically compatible with T. gondii. The immunohistochemical and polymerase chain reaction (PCR) analysis targeting a repetitive 529-bp DNA fragment of $T$. gondii confirmed toxoplasmosis in the liver, spleen, lung, and lymph nodes. PCR-restriction fragment length polymorphism analysis using 11 markers identified a new nonarchetypal genotype, ToxoDB-RFLP genotype \#300. Further, the genotyping by microsatellite technique employed 15 markers and confirmed a unique non-archetypal T. gondii strain, designated as PS-TgBaledBrES1. These novel results add to the diversity of this parasite in the world and to the scarce data on T. gondii genotype distribution in cetaceans, representing the first record of toxoplasmosis in a Bryde's whale and setting the baseline knowledge for future research on T. gondii genotyping research in marine mammals from South America.

Keywords: sarcocystidae, toxoplasmosis, genotyping, Bryde's whale, cetacean, marine mammal 


\section{INTRODUCTION}

Toxoplasma gondii (phylum Apicomplexa), an intracellular protozoan parasite responsible for toxoplasmosis, affects a wide number of hosts including non-human animals and humans with varying morbidity and mortality (Howe and Sibley, 1995; Dubey, 2010; Calero-Bernal and Gennari, 2019). Notwithstanding, T. gondii is known to cause sporadic clinical disease and fatality in marine mammals in many geographic areas. It is considered emergent in certain locations, such as the Arctic (Donahoe et al., 2014). T. gondii was first described in Brazil and Tunisia in 1908 (Nicolle and Manceaux, 1908; Splendore, 1908; Ferguson, 2009). Furthermore, the first record of toxoplasmosis in cetaceans was in a Guiana dolphin (Sotalia guianensis) from Rio de Janeiro state, Brazil, in the 1970s (Bandoli and Oliveira, 1977). Since then, knowledge on the exposure and the infection of this protozoan has been gained primarily by serological, pathological, and molecular techniques in a wide variety of captive and freeranging cetaceans worldwide (Inskeep et al., 1990; Omata et al., 2006; Mazzariol et al., 2012; Gonzales-Viera et al., 2013; CostaSilva et al., 2019).

In recent years, $T$. gondii has increasingly been recognized in odontocetes, pinnipeds, and mustelids (Van Wormer et al., 2016; Reisfeld et al., 2019; Shapiro et al., 2019). Nonetheless, there is very limited information in mysticetes, including a seropositive humpback whale (Megaptera novaeangliae) from the Atlantic Ocean (Forman et al., 2009) and a fin whale (Balaenoptera physalus) co-infected with Cetacean Morbillivirus (CeMV) in the Mediterranean Sea (Mazzariol et al., 2012). The Bryde's whale (B. edeni) is one of the least known baleen whales (Kato and Perrin, 2008) being currently regarded as "data deficient" by the International Union for Conservation of Nature (Redlist of threatened species, 2013). The geographical location of the Bryde's whale ranges from $40^{\circ} \mathrm{N}$ to $40^{\circ} \mathrm{S}$ in tropical and temperate waters, including the Indian, North and South Pacific, and Atlantic oceans (Kato and Perrin, 2008). This species occurs regularly along the coast off the states of São Paulo and Rio de Janeiro, southeastern Brazil (Lodi et al., 2015).

Toxoplasma gondii has been typically regarded as a secondary or opportunistic pathogen for cetaceans (Migaki et al., 1990; Domingo et al., 1992; Kennedy, 1998; Mikaelian et al., 2000; Dubey et al., 2008; Van Bressem et al., 2009), yet various reports have suggested its primary pathogenic role in the absence of evident concomitant disease and/or demonstrated toxicologic stress levels (Miller et al., 2001; Di Guardo et al., 2011; GonzalesViera et al., 2013). Genotyping of T. gondii may provide insight into the dynamics of the protozoan at terrestrial and aquatic environments and their interfaces with implications for public health. Three clonal lineages (I, II, and III) and various atypical (non-archetypal) strains are described based on their variability in genetic markers and pathogenicity in mice (Howe and Sibley, 1995; Ajzenberg et al., 2004; Pena et al., 2008; Sibley et al., 2009; Shwab et al., 2014). Overall, there is very limited information available on T. gondii genotypes affecting marine mammals. In North America, the T. gondii genotypes identified in marine mammals include types I, II, X, and A (Conrad et al., 2005; Dubey, 2010; Gibson et al., 2011). Interestingly, most human infections in
North America and Europe are linked to type II $T$. gondii, which is also common in livestock in these regions (Sibley et al., 2009). Type II and atypical type II T. gondii isolates were detected in striped dolphins (Stenella coeruleoalba) stranded on the Ligurian Sea coast of Italy (Di Guardo et al., 2011). Atypical type II genotypes were also recently identified in Hector's dolphins (Cephalorhynchus hectori) from New Zealand (Roe et al., 2013) and a fur seal (Arctocephalus forsteri) from New South Wales, Australia (Donahoe et al., 2014). Given the relatively limited knowledge on T. gondii genotype distribution among marine mammals worldwide and more specifically in Brazil, as well as the elusive potential epidemiological associations with public health and terrestrial T. gondii epidemiology, this study aimed at reporting the results of pathological, immunohistochemical, and molecular genotyping analyses in a Bryde's whale with disseminated toxoplasmosis.

\section{METHOD}

A 10.7-m-long, adult, male Bryde's whale was stranded alive on August 21, 2018 in "Pontal do Ipiranga," Linhares, Espirito Santo state (Brazil). The animal died shortly after stranding and autopsy was performed promptly as per standard protocol (Geraci and Lounsbury, 2005). Representative tissue samples of the heart, aorta, lung, trachea, mediastinal, pulmonary, tracheobronchial, mesenteric and prescapular lymph nodes, diaphragm, tongue, stomach, intestine, liver, kidney, urinary bladder, spleen, pancreas, testicle, epididymis, skin, rectus abdominis, and longissimus dorsi were collected and fixed in $10 \%$ neutral buffered formalin. All these tissues were processed routinely and embedded in paraffin wax, and 5$\mu \mathrm{m}$-thick sections were stained with hematoxylin and eosin (H\&E) for microscopic analysis. Selected tissue samples were collected and kept frozen $\left(-20^{\circ} \mathrm{C}\right)$ for molecular analyses. For immunohistochemistry (IHC), a primary polyclonal antiT. gondii antibody (1:400 dilution; VMRD Inc., Pullman, WA, United States) was employed, followed by an avidin-biotinperoxidase complex method (Elite ABC kit, Vector Laboratories, Burlingame, CA, United States) (Costa-Silva et al., 2019), in the lung, liver, spleen, and lymph node (prescapular, pulmonary, mediastinal, and mesenteric) tissue sections. A positive control included the adrenal gland from a T. gondii-positive Guiana dolphin (Gonzales-Viera et al., 2013). As negative control, sequential tissue sections were incubated with non-immune homologous serum.

For the molecular analysis, tissue fragments $(\sim 1 \mathrm{~g}$ each $)$ of lung, liver, spleen, and lymph nodes (prescapular, mediastinal, pulmonary, and mesenteric) were homogenized separately with $500 \mu \mathrm{l}$ of Tris-ethylenediaminetetraacetic acid (EDTA) buffer (10 mM Tris-HCl and $1 \mathrm{mM}$ EDTA, $\mathrm{pH}$ 8.0) using a pestle and a mortar. Furthermore, $250 \mu \mathrm{l}$ of each homogenate was used with a commercial kit (DNeasy Blood ${ }^{\circledR}$ \& Tissue kit, Qiagen, Hilden, Germany) for DNA extraction, according to the manufacturer's instructions. A polymerase chain reaction (PCR) targeting the amplification of the repetitive 529-bp fragment from $T$. gondii genome was employed for the molecular detection 
of T. gondii (Homan et al., 2000). PCR-restriction fragment length polymorphism (RFLP) was performed to identify the genotypes of T. gondii. Reference archetypal strains RH (type I), PTG (type II), and CTG (type III) and T. gondii nonarchetypal strains ( $\mathrm{TgCgCa1}, \mathrm{MAS}$, and $\mathrm{TgCatBr} 5$ ) were included as positive controls in all reactions. The following markers were used: SAG1, 5' $3^{\prime}$ SAG2 and alternatively SAG2, SAG3, BTUB, GRA6, c22-8, c29-2, L358, PK1, Apico (Su et al., 2010), and CS3 (Pena et al., 2008). The genotyping by microsatellite (MS) technique employed 15 markers (TUB2, W35, TgM-A, B18, B17, M33, MIV.1, MX1, M48, M102, N60, N82, AA, N61, and N83) (Ajzenberg et al., 2010). The reference archetypal strain PTG was used as the positive control. An automatic sequencer (3500 Genetic analyzer AB Hitachi, Life Tech, São Paulo, Brazil) and the GeneMapper software (version 4.1; Applied Biosystems) were used for electrophoresis and fragment analysis, respectively. All DNA from the positive controls used in this study were kindly provided by Dr. Chunlei Su from the Department of Microbiology, The University of Tennessee, Knoxville, Knoxville, TN, United States. This study was approved by the Instituto Chico Mendes de Conservação da Biodiversidade and was conducted under SISBIO license \#48279-4. This study is in agreement with the Ethical Principles in Animal Research adopted by the "Ethic Committee in the Use of Animals" of the School of Veterinary Medicine and Animal Science of the University of São Paulo (protocol \#5580110315).

\section{RESULTS}

Grossly, the main pathologic findings were diffuse axial skeletal muscle atrophy, systemic congestion, petechiation, ecchymoses, necrotizing splenitis, hepatitis, myocarditis, pneumonia, lymphadenitis (prescapular, pulmonary, mediastinal, and mesenteric), bilateral scapulohumeral hemarthros, and severe pulmonary edema (Figure 1). Microscopically, the lymphoid system had marked, multifocal to coalescing, acute multicentric necrotizing lymphadenitis and splenitis with necrotizing vasculitis and thrombosis. The liver had marked, multifocal to coalescing, acute necrotizing hepatitis with vasculitis and thrombosis. In the respiratory system, there was marked, diffuse, acute fibrinonecrotizing interstitial pneumonia with abundant hyaline membranes, vasculitis, and thrombosis. The cardiovascular system had mild to moderate, multifocal, acute/subacute lymphohistiocytic myocarditis with necrosis and hemorrhage and moderate, multifocal, chronic fibrosing endarteritis and endocarditis with hemorrhage. In the reproductive system, there was necrotizing orchitis and periorchitis with hemorrhage and acute neutrophilic and lymphohistiocytic epididymitis with vasculitis and hemorrhage. In the digestive system, there was multifocal, acute enteritis with fibrin and edema and mild, multifocal, acute necrotizing gastric leiomyositis with vasculitis and fibrin. The inflammatory foci in all the aforementioned organs had moderate to large numbers of protozoan cysts and extracellular tachyzoites morphologically compatible with $T$. gondii (Figure 2). Additional relevant pathologic findings non-related to toxoplasmosis were those attributed to live stranding stress response, primarily characterized by acute, hyaline segmental myodegeneration and necrosis in the rectus abdominis and longissimus dorsi muscles.

Results of the immunohistochemistry showed cysts and tachyzoites in tissues (Figure 2). All analyzed whale tissues were T. gondii-positive by the 529-bp fragment PCR. This strain from B. edeni was designated as PS-TgBaledBrES1. Based on genotyping by PCR-RFLP and MS analysis, the novel ToxoDBRFLP genotype $\# 300^{1}$ (Table 1), a non-archetypal, unique genotype (Table 2), was revealed in all the samples analyzed.

\section{DISCUSSION}

Fatal toxoplasmosis in marine mammals often is associated with hepatitis, meningoencephalitis, adrenalitis, lymphadenitis, interstitial pneumonia, retinochoroiditis, thymitis, placentitis, and myocarditis. Early embryonic death and resorption, fetal death and mummification, and stillbirth and neonatal death may be seen in animals with transplacental infections (Inskeep et al., 1990; Migaki et al., 1990; Jardine and Dubey, 2002; Resendes et al., 2002; Dubey et al., 2008; Dubey, 2010). In the present case, the pathological signature was characterized by multisystemic necrotizing inflammation with vasculitis and disseminated intravascular coagulation with thrombosis and myriads of intralesional protozoal cysts morphologically compatible with $T$. gondii. These pathological findings are analogous to various previous reports of fatal systemic acute toxoplasmosis in susceptible marine and terrestrial animal species, including man (Dubey and Jones, 2008). To the best of our knowledge, only one previous report documented toxoplasmosis in a mysticete, specifically a fin whale (Mazzariol et al., 2012). Although no pathological findings were observed in the latter (probably related to decomposition status), the IHC analysis revealed protozoan cysts in kidney and heart (Mazzariol et al., 2012). Moreover, the PCR analyses detected T. gondii genomic sequences in renal, cardiac, and skeletal muscle and in mesenteric lymph node (Mazzariol et al., 2012). The whale had positive PCR results for CeMV but no evident morbilliviral antigen in the tissues examined (Mazzariol et al., 2012). The findings observed in the present case suggest that $T$. gondii may be a cause of severe systemic infection and death in Bryde's whales, widening the host record for this pathogenic protozoan. Immunosuppression by chemical pollutants, such as polychlorinated biphenyls, or concurrent infections, such as CeMV, are known predisposing factors for toxoplasmosis in cetaceans (Mikaelian et al., 2000; Di Guardo and Mazzariol, 2013; Lair et al., 2016). In this case, CeMV infection was ruled out on the basis of immunohistochemical and molecular analyses (data not shown). We did not perform toxicologic analyses; thus, potential chemical pollutant-based immunosuppression could not be excluded in this case.

The genus Toxoplasma consists of only one species that shows a clonal population structure in the northern hemisphere with few dominant genotypes and an epidemic population structure in the southern hemisphere with high diversity, particularly in

\footnotetext{
${ }^{1}$ http://toxodb.org/toxo/
} 


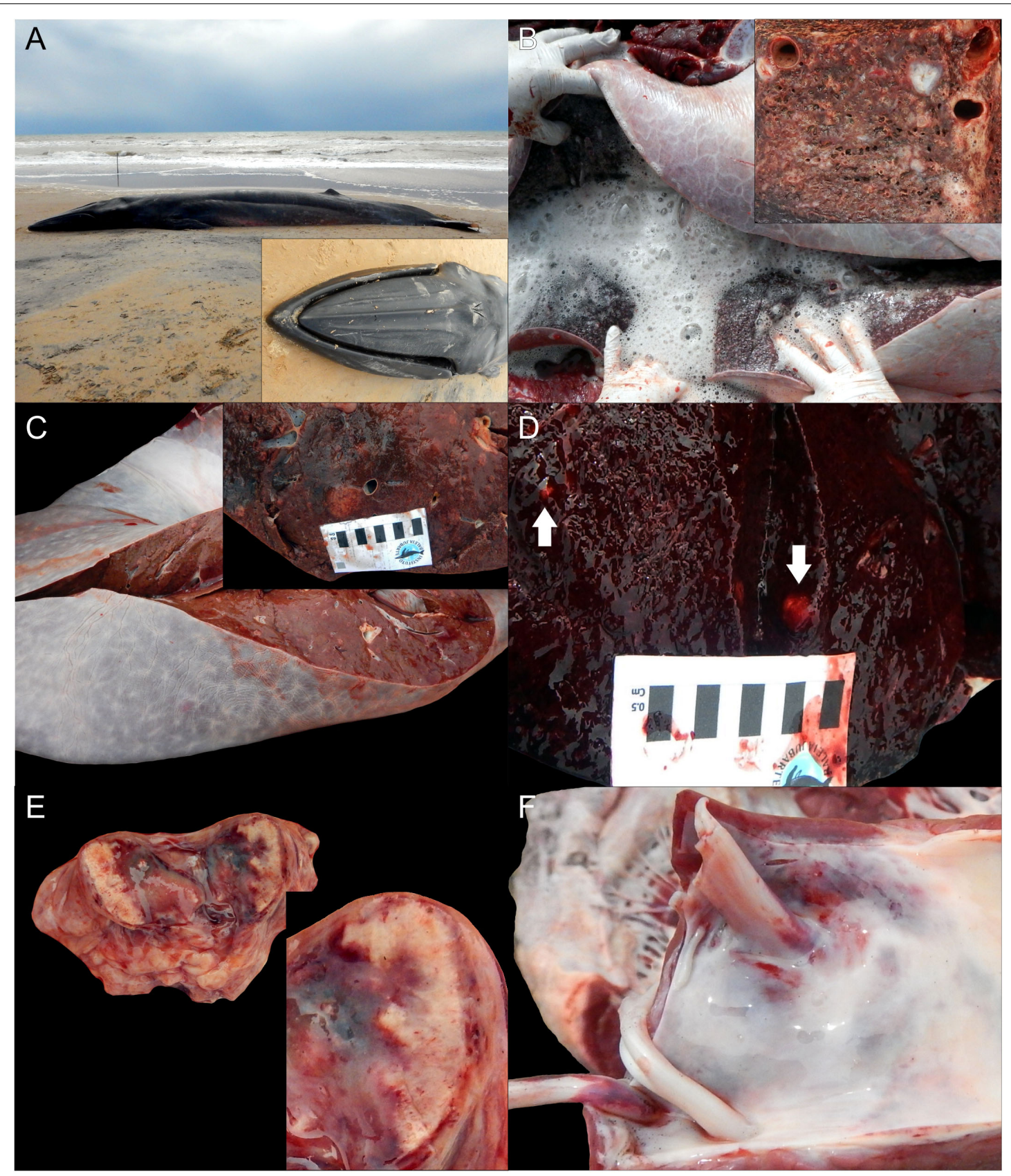

FIGURE 1 | Macroscopic findings in a Bryde's whale (Balaenoptera edeni) with disseminated toxoplasmosis. (A) Whole body, left lateral view. Inset: characteristic three rostral cephalic ridges used as morphologic identification criterion. (B) Severe pulmonary edema. Inset: necrotizing interstitial pneumonia. (C) Necrotizing hepatitis. Inset: greater detail of necrotizing hepatitis. (D) Necrotizing splenitis. The arrows indicate the foci of necrosis. (E) Necrotizing lymphadenitis. Inset: greater detail of necrotizing lymphadenitis. (F) Endocardial hemorrhages.

Central and South America (Shwab et al., 2014). RFLP genotype \#1 (type II), \#2 (type III), \#3 (type II variant), and \#10 (type I) are identified globally. Genotypes \#2 and \#3 dominate in Africa, genotypes \#9 and \#10 are prevalent in Asia, genotypes \#1, \#2, and \#3 are prevalent in Europe, and genotypes \#1, \#2, \#3, \#4, and \#5 dominate in North America. In Central and South America, there is no clear dominance of any genotype, even though a few have relatively higher frequencies (Shwab et al., 2014). In
Brazil, considering all published studies, the three most frequent genotypes are \#6 (Type BrI), \#11 (Type BrII), and \#13 (Pena et al., 2008; Shwab et al., 2014; Feitosa et al., 2017). There are limited reports of T. gondii with genotyping characterization in marine mammals, particularly in cetaceans. The three clonal lineages are sporadically reported in marine mammals, but other genotypes (atypical, type A, type $\mathrm{X}$, and type 12) appear to be common (Jardine and Dubey, 2002; Conrad et al., 2005; Miller et al., 




FIGURE 2 | Microscopic findings in a Bryde's whale (Balaenoptera edeni) with disseminated toxoplasmosis. (A) Liver: marked, multifocal random to coalescing, acute necrotizing hepatitis. H\&E, $\times 40$. Right upper inset: focus of necrotizing hepatitis (asterisk) and two adjacent protozoal cysts (arrows). H\&E, $\times 400$. Right lower inset: protozoal cysts immunolabeled by anti-Toxoplasma gondii antibody. Immunohistochemistry, $\times 1,000$. (B) Spleen: fibrinous exudate and necrotic cell debris along with loss of cellular detail and hemorrhage. H\&E, $\times 100$. Inset: detail of intracytoplasmic endothelial protozoal cyst. H\&E, $\times 1,000$. (C) Pulmonary lymph node: necrotizing lymphadenitis with extensive lymphoid loss and focal capsular obliterative fibrinocellular thrombus (asterisk). H\&E, $\times 40$. Inset: intracellular protozoal cyst amidst fibrinonecrotizing inflammation. H\&E, $\times 40$. (D) Lung: abundant fibrin layers coating the alveolar septa with necrotic pneumocytes and inflamed septa. H\&E, $\times 100$.

2004; Honnold et al., 2005; Dubey et al., 2007, 2008, 2009, 2011; Sundar et al., 2008; Dubey, 2010; Gibson et al., 2011). Molecular analyses in stranded St. Lawrence Estuary (Québec, Canada) belugas identified primarily genotype II (Iqbal et al., 2018), which predominates in humans from North America and Europe, and two new atypical genotypes of T. gondii (De Guise et al., 1995; Mikaelian et al., 2000; Haman et al., 2013; Lair et al., 2016). Interestingly, in North America and Europe, type II T. gondii is also common in livestock (Sibley et al., 2009).

Mixed or atypical infections of genotypes with unique alleles, combinations of alleles, or multiple genotypes have been rarely documented in marine mammals (Gibson et al., 2011). Types X, A, and II-like were shown to comprise a new 4th clonal lineage, haplogroup 12 (Dubey et al., 2011; Khan et al., 2011). Type II and atypical type II T. gondii isolates were detected in striped dolphins (S. coeruleoalba) stranded on the Ligurian Sea coast of Italy (Di Guardo et al., 2011). Atypical type II genotypes were also recently identified in Hector's dolphins (C. hectori) from New Zealand (Roe et al., 2013) and a fur seal (A. forsteri) from New South Wales, Australia (Donahoe et al., 2014). In the present case, the genotyping results identified a novel non-archetypal T. gondii, which in this case appears to be highly pathogenic for the whale host species, although many factors other than strain type can be related to pathogenicity, including dose, infective stage, and immunity status. The potential public health implications/associations of this novel non-archetypal T. gondii remain elusive in this case due to lack of identical isolates to date. It is worth mentioning that there is potential risk for transmission of $T$. gondii by whale meat consumption in geographic areas where this practice may still occur, including Brazil (Lima et al., 2006a).

The transmission pathways through which "inshore" and "offshore" cetaceans acquire T. gondii infection remain uncertain. Three main infective stages of $T$. gondii are recognized: (1) sporozoites (in sporulated oocysts), (2) bradyzoites (in tissue cysts of intermediate hosts), and (3) tachyzoites (Dubey et al., 1998). T. gondii oocysts have been demonstrated in runoff waters, shellfish, and filter-feeding fish (Van Bressem et al., 2009; Massie et al., 2010; Putignani et al., 2011). Multiple T. gondii genotypes have been reported in marine invertebrates (Shapiro 
TABLE 1 | Toxoplasma gondii PCR-restriction fragment length polymorphism genotype from a Bryde's whale (Balaenoptera edeni) stranded in Pontal do Ipiranga, Linhares, Espirito Santo state (Brazil).

\begin{tabular}{|c|c|c|c|c|c|c|c|c|c|c|c|c|c|c|c|}
\hline \multirow[t]{2}{*}{ Sample ID } & \multirow[t]{2}{*}{ Host } & \multirow[t]{2}{*}{ MS type } & \multirow[t]{2}{*}{ ToxoDB RFLP \# } & \multicolumn{12}{|c|}{ Genetic markers } \\
\hline & & & & SAG1 & 5'3'SAG2 & altSAG2 & SAG3 & BTUB & GRA6 & c22-8 & c29-2 & L358 & PK1 & Apico & cs3 \\
\hline PS-TgBaledBrES1 & Balaenoptera edeni & Non-archetypal & 300 & 1 & 1 & $\|$ & III & 1 & III & $\|$ & 1 & 1 & I & 1 & $\|$ \\
\hline
\end{tabular}

TABLE 2 | Genotyping results of Toxoplasma gondii with 15 microsatellite markers from a Bryde's whale (Balaenoptera edeni) stranded in Pontal do Ipiranga, Linhares, Espirito Santo state (Brazil).

\begin{tabular}{|c|c|c|c|c|c|c|c|c|c|c|c|c|c|c|c|c|c|c|}
\hline \multirow[t]{2}{*}{ Sample ID } & \multirow[t]{2}{*}{ Host } & \multirow[t]{2}{*}{ MS type } & \multirow[t]{2}{*}{ ToxoDB RFLP \# } & \multicolumn{15}{|c|}{ Microsatellite markers } \\
\hline & & & & TUB2 & w35 & $\operatorname{TgM}-A$ & B18 & B17 & Мз3 & IV.1 & $X I .1$ & M48 & M102 & $N 60$ & N82 & $A A$ & $N 61$ & N83 \\
\hline PS-TgBaledBrES1 & Balaenoptera edeni & Non-archetypal & 300 & 291 & 248 & 205 & 162 & 342 & 165 & 278 & 358 & 235 & 164 & 171 & 111 & 295 & 89 & 306 \\
\hline
\end{tabular}

Marker names in bold are the typing markers. 
et al., 2015). Furthermore, oocysts may survive in seawater and remain infective for up to 6 months (Lindsay and Dubey, 2009). Domestic and wild felids are the only known definitive hosts, shedding unsporulated oocysts. After sporulation, the oocysts can be infectious to susceptible intermediate hosts, which include most vertebrate species (Dubey, 2010). The carnivorous intermediate hosts can also become infected by consuming tissue cysts within other intermediate hosts (Dubey, 2010).

The source of T. gondii infection in the present Bryde's whale is unknown. In Brazil, in the post-whaling era, Bryde's whales are reported mainly along the southeastern coast (Gonçalves and Andriolo, 2006; Figueiredo et al., 2015; Lodi et al., 2015) and in offshore areas of São Paulo (Goncalves et al., 2016). This species primarily occurs in deep waters far off the coast (Andriolo et al., 2010) at different depths and at relatively high densities in upwelling areas (Wiseman et al., 2011; Forney et al., 2012; Weir et al., 2012). It possibly uses coastal areas for feeding and may migrate to oceanic areas for breeding (Goncalves et al., 2016). Sardines (Siciliano et al., 2004), Engraulidae fish (Lima et al., 2006b), aviu shrimp (Acetes americanus) (Moura and Siciliano, 2012), snubnose anchovy (Anchoviella brevirostris), and white snake mackerel (Thyrsitops lepidopoides) are part of the known diet of Bryde's whale in Brazil (Lodi et al., 2015). Recent evidence showed Bryde's whales feeding in the coastal waters of Brazil, primarily preying upon sardines (Goncalves et al., 2016). Furthermore, in coastal waters, the likelihood of exposure to runoff waters and interactions with seabirds increases. Interestingly, sardines and anchovies are able to pass $T$. gondii oocysts in their feces (Massie et al., 2010). If exposed to contaminated nearshore waters, sardines could then serve as biotic vectors for T. gondii in neritic and oceanic waters (offshore migrations) (Marino et al., 2019). Waterborne T. gondii exposure by infective oocysts in polluted water is an increasingly recognized source of infection. Surface water runoff tributes to coastal streams or directly to the ocean from urban and non-urban areas with no pre-treatment (Miller et al., 2002). Seabirds, including Brazilian species of orders Suliformes and Phaethontiformes, are known to be exposed to T. gondii (Gennari et al., 2016); however, their potential contribution to $T$. gondii transmission from land to sea environments remains unknown. From the discussion above, the ingestion of infecting oocysts or cysts from the water column or preys is the most plausible possibility in this case. Unfortunately, this whale had no solid gastrointestinal contents that might shed some light into a potential prey-associated T. gondii transmission. Further source and transmission-related conclusions are precluded by the lack of any previous report on this novel non-archetypal T. gondii strain, which also highlights the genetic diversity yet to be reported of the agent.

\section{CONCLUDING REMARKS}

In summary, we documented a case of fatal, acute systemic toxoplasmosis in a Bryde's whale stranded in Brazil. The pathologic signature in this animal was characterized by multisystemic necrotizing inflammation with vasculitis and disseminated intravascular coagulation with thrombosis and numerous intralesional protozoan cysts and extracellular tachyzoites morphologically compatible with $T$. gondii. This pathogen was further confirmed by IHC and PCR analyses. PCR-RFLP and MS techniques identified a novel non-archetypal T. gondii called PS-TgBaledBrES1 (ToxoDB-RFLP genotype \#300). These novel results add to the scarce data on T. gondii genotype distribution in cetaceans, represent the first record of toxoplasmosis in a Bryde's whale, and set the baseline knowledge for future research on $T$. gondii genotyping research in marine mammals from South America.

\section{DATA AVAILABILITY STATEMENT}

The datasets generated for this study can be found in the http: //toxodb.org/toxo.

\section{ETHICS STATEMENT}

Ethical review and approval was not required for the animal study because no specific ethical review and approval was required for this particular study involving a single stranded marine mammal. However, our laboratory and our coworkers' research projects operate with multiple permits from multiple institutions including the Brazilian Government.

\section{AUTHOR CONTRIBUTIONS}

JD-D, KG, HR, AC, and JC-D contributed to the conception and design of the study. $\mathrm{HR}$ and $\mathrm{AC}$ performed the necropsy examination. JD-D, KG, and JC-D conducted histopathological, immunohistochemical, and molecular analyses. BA and HP conducted molecular analyses. JD-D and KG wrote the first draft of the manuscript. All the authors contributed to manuscript revision and read and approved the submitted version.

\section{FUNDING}

The authors are grateful to Dr. Larissa Pavanelli, volunteers and staff members of the Instituto Baleia Jubarte and CTAMeio Ambiente for their assistance in necropsy procedures. The rescue program was carried out as required by state environmental licensing of the Terminal Marítimo de Belmonte-BA, conducted by INEMA. This study comprised a parallel research initiative while conduction of postdoctoral fellowship projects funded by São Paulo Research Foundation (FAPESP Grants \#2014/24932-2; \#2017/243352; \#2017/02223-8; and \#2018/01876). This research was also supported by Coordination for the Improvement of Higher Education Personnel - Brazil (CAPES), finance code 001 PNPD grant \#1812894. JC-D is the recipient of a fellowship by the National Research Council (CNPq; grant \#304999/2018-0). 


\section{REFERENCES}

Ajzenberg, D., Banuls, A. L., Su, C., Dumetre, A., Demar, M., Carme, B., et al. (2004). Genetic diversity, clonality and sexuality in Toxoplasma gondii. Int. J. Parasitol. 34, 1185-1196. doi: 10.1016/j.ijpara.2004.06.007S0020-7519(04) 00139-0

Ajzenberg, D., Collinet, F., Mercier, A., Vignoles, P., and Dardé, M. L. (2010). Genotyping of Toxoplasma gondii isolates with 15 microsatellite markers in a single multiplex PCR assay. J. Clin. Microbiol. 48, 4641-4645. doi: 10.1128/jcm. 01152-10

Andriolo, A., Da Rocha, J. M., Zerbini, A. N., Simões-Lopes, P. C., Moreno, I. B., Lucena, A., et al. (2010). Distribution and relative abundance of large whales in a former whaling ground off eastern South America. Zoologia 27, 741-750. doi: 10.1590/s1984-46702010000500011

Bandoli, J. G., and Oliveira, C. A. B. (1977). Toxoplasmose em Sotalia guianensis (Van Beneden 1863), Cetacea-Delphinidae. Folha Méd. 75, 459-468.

Calero-Bernal, R., and Gennari, S. M. (2019). Clinical toxoplasmosis in dogs and cats: an update. Front. Vet. Sci. 6:54. doi: 10.3389/fvets.2019.00054

Conrad, P. A., Miller, M. A., Kreuder, C., James, E. R., Mazet, J., Dabritz, H., et al. (2005). Transmission of Toxoplasma: clues from the study of sea otters as sentinels of Toxoplasma gondii flow into the marine environment. Int. J. Parasitol. 35, 1155-1168. doi: 10.1016/j.ijpara.2005.07.002

Costa-Silva, S., Sacristán, C., Gonzales-Viera, O., Díaz-Delgado, J., SánchezSarmiento, A. M., Marigo, J., et al. (2019). Toxoplasma gondii in cetaceans of Brazil: a histopathological and immunohistochemical survey. Rev. Bras. Parasitol. 28:51.

De Guise, S., Lagace, A., Beland, P., Girard, C., and Higgins, R. (1995). Nonneoplastic lesions in beluga whales (Delphinapterus leucas) and other marine mammals from the St Lawrence Estuary. J. Comp. Pathol. 112, 257-271. doi: 10.1016/s0021-9975(05)80079-9

Di Guardo, G., Di Cesare, A., Otranto, D., Casalone, C., Iulini, B., Mignone, W., et al. (2011). Genotyping of Toxoplasma gondii isolates in meningo-encephalitis affected striped dolphins (Stenella coeruleoalba) from Italy. Vet. Parasitol. 183, 31-36. doi: 10.1016/j.vetpar.2011.07.004S0304-4017(11)00473-0

Di Guardo, G., and Mazzariol, S. (2013). Toxoplasma gondii: clues from stranded dolphins. Vet. Pathol. 50:737. doi: 10.1177/030098581348681650/5/737

Domingo, M., Visa, J., Pumarola, M., Marco, A. J., Ferrer, L., Rabanal, R., et al. (1992). Pathologic and immunocytochemical studies of morbillivirus infection in striped dolphins (Stenella coeruleoalba). Vet. Pathol. 29, 1-10. doi: 10.1177/ 030098589202900101

Donahoe, S. L., Rose, K., and Slapeta, J. (2014). Multisystemic toxoplasmosis associated with a type II-like Toxoplasma gondii strain in a New Zealand fur seal (Arctocephalus forsteri) from New South Wales, Australia. Vet. Parasitol. 205, 347-353. doi: 10.1016/j.vetpar.2014.07.022S0304-4017(14)00409-9

Dubey, J. P. (2010). Toxoplasmosis of Animals And Humans. New York, NY: CRC Press.

Dubey, J. P., Fair, P. A., Sundar, N., Velmurugan, G., Kwok, O. C., McFee, W. E., et al. (2008). Isolation of Toxoplasma gondii from bottlenose dolphins (Tursiops truncatus). J. Parasitol. 94, 821-823. doi: 10.1645/GE-1444.1GE-1444

Dubey, J. P., and Jones, J. L. (2008). Toxoplasma gondii infection in humans and animals in the United States. Int. J. Parasitol. 38, 1257-1278. doi: 10.1016/j. ijpara.2008.03.007S0020-7519(08)00110-0

Dubey, J. P., Lindsay, D. S., and Speer, C. A. (1998). Structures of Toxoplasma gondii tachyzoites, bradyzoites, and sporozoites and biology and development of tissue cysts. Clin. Microbiol. Rev. 11, 267-299. doi: 10.1128/cmr.11.2.267

Dubey, J. P., Mergl, J., Gehring, E., Sundar, N., Velmurugan, G. V., Kwok, O. C., et al. (2009). Toxoplasmosis in captive dolphins (Tursiops truncatus) and walrus (Odobenus rosmarus). J. Parasitol. 95, 82-85. doi: 10.1645/GE-1764.1GE-1764

Dubey, J. P., Morales, J. A., Sundar, N., Velmurugan, G. V., Gonzalez-Barrientos, C. R., Hernandez-Mora, G., et al. (2007). Isolation and genetic characterization of Toxoplasma gondii from striped dolphin (Stenella coeruleoalba) from Costa Rica. J. Parasitol. 93, 710-711. doi: 10.1645/GE-1120R.1

Dubey, J. P., Velmurugan, G. V., Rajendran, C., Yabsley, M. J., Thomas, N. J., Beckmen, K. B., et al. (2011). Genetic characterisation of Toxoplasma gondii in wildlife from North America revealed widespread and high prevalence of the fourth clonal type. Int. J. Parasitol. 41, 1139-1147. doi: 10.1016/j.ijpara.2011.06. 005

Feitosa, T. F., Vilela, V. L. R., de Almeida-Neto, J. L., dos Santos, A., de Morais, D. F., Alves, B. F., et al. (2017). High genetic diversity in Toxoplasma gondii isolates from pigs at slaughterhouses in Paraíba state, northeastern Brazil: circulation of new genotypes and Brazilian clonal lineages. Vet. Parasitol. 244, 76-80. doi: 10.1016/j.vetpar.2017.07.017

Ferguson, D. J. (2009). Toxoplasma gondii: 1908-2008, homage to Nicolle, Manceaux and Splendore. Mem. Inst. Oswaldo. Cruz. 104, 133-148. doi: 10. 1590/s0074-02762009000200003

Figueiredo, L. D., Tardin, R. H., Maciel, I. S., Alves, M. A. S., and Simao, S. M. (2015). Site fidelity of Bryde's whales (Balaenoptera edeni) in cabo frio region, southeastern Brazil, through photoidentification technique. Braz. J. Aquat. Sci. Tech. 18, 59-64.

Forman, D., West, N., Francis, J., and Guy, E. (2009). The seroprevalence of Toxoplasma gondii in British marine mammals. Mem. Inst. Oswaldo. Cruz. 104, 296-298. doi: 10.1590/s0074-02762009000200024

Forney, K. A., Ferguson, M. C., Becker, E. A., Fiedler, P. C., Redfern, J. V., Barlow, J., et al. (2012). Habitat-based spatial models of cetacean density in the eastern Pacific Ocean. Endang. Spec. Res. 16, 113-133. doi: 10.3354/esr00393

Gennari, S. M., Niemeyer, C., Soares, H. S., Musso, C. M., Siqueira, G. C., CataoDias, J. L., et al. (2016). Seroprevalence of Toxoplasma gondii in seabirds from abrolhos archipelago, Brazil. Vet. Parasitol. 226, 50-52. doi: 10.1016/j.vetpar. 2016.06.016

Geraci, J. R., and Lounsbury, V. J. (2005). Marine Mammals Ashore: A Field Guide for Strandings. Baltimore, MD: National Aquarium in Baltimore.

Gibson, A. K., Raverty, S., Lambourn, D. M., Huggins, J., Magargal, S. L., and Grigg, M. E. (2011). Polyparasitism is associated with increased disease severity in Toxoplasma gondii-infected marine sentinel species. PLoS Neglect. Trop. D 5:1142. doi: 10.1371/journal.pntd.0001142

Gonçalves, L., and Andriolo, A. (2006). Ocorrência, distribuição e comportamento de Baleias-de-Bryde (Balaenoptera edeni Anderson, 1879) (Cetacea, Mysticeti) em áreas costais e oceânicas do sudeste do Brasil. Rev. Bras. Zooc. 8:213.

Goncalves, L. R., Augustowski, M., and Andriolo, A. (2016). Occurrence, distribution and behaviour of Bryde's whales (Cetacea: Mysticeti) off south-east Brazil. J. Mar. Biol. Assoc. U.K. 96, 943-954. doi: 10.1017/S0025315415001812

Gonzales-Viera, O., Marigo, J., Ruoppolo, V., Rosas, F. C. W., Kanamura, C. T., Takakura, C., et al. (2013). Toxoplasmosis in a Guiana dolphin (Sotalia guianensis) from Parana, Brazil. Vet. Parasitol. 191, 358-362. doi: 10.1016/j. vetpar.2012.09.012

Haman, K. H., Raverty, S., Wendte, J. M., Loseto, L., Ferguson, S. H., and Grigg, M. E. (2013). “Toxoplasma gondii infected tissues from hunter harvested beluga (Delphinapterus leucas) in the Western Canadian Arctic," in Proceedings of the 44th Annual IAAAM Conference, (California: The Marine Mammal Center Sausalito).

Homan, W. L., Vercammen, M., De Braekeleer, J., and Verschueren, H. (2000). Identification of a 200-to 300 -fold repetitive 529 bp DNA fragment in Toxoplasma gondii, and its use for diagnostic and quantitative PCR. Int. J. Parasitol. 30, 69-75. doi: 10.1016/s0020-7519(99)00170-8

Honnold, S. P., Braun, R., Scott, D. P., Sreekumar, C., and Dubey, J. P. (2005). Toxoplasmosis in a Hawaiian monk seal (Monachus schauinslandi). J. Parasitol. 91, 695-697. doi: 10.1645/GE-469R

Howe, D. K., and Sibley, L. D. (1995). Toxoplasma gondii comprises three clonal lineages: correlation of parasite genotype with human disease. J. Infect. Dis. 172, 1561-1566. doi: 10.1093/infdis/172.6.1561

Inskeep, W., Gardiner, C. H., Harris, R. K., Dubey, J. P., and Goldston, R. T. (1990). Toxoplasmosis in atlantic bottle-nosed Dolphins (Tursiops truncatus). J. Wildl. Dis. 26, 377-382. doi: 10.7589/0090-3558-26.3.377

Iqbal, A., Measures, L., Lair, S., and Dixon, B. (2018). Toxoplasma gondii infection in stranded St. Lawrence Estuary beluga Delphinapterus leucas in Quebec, Canada. Dis. Aquat. Organ. 130, 165-175. doi: 10.3354/dao03262

Jardine, J. E., and Dubey, J. P. (2002). Congenital toxoplasmosis in a Indo-Pacific bottlenose dolphin (Tursiops aduncus). J. Parasitol. 88, 197-199. doi: 10.1645/ 0022-3395(2002)088[0197:ctiaip]2.0.co;2

Kato, H., and Perrin, W. F. (2008). "Bryde's whale," in Encyclopedia of Marine Mammals, eds W. F. Perrin, B. Würsig, and J. G. M. Thewissen (Chicago, IL: Academic Press), 158-162.

Kennedy, S. (1998). Morbillivirus infections in aquatic mammals. J. Comp. Pathol. 119, 201-225. doi: 10.1016/s0021-9975(98)80045-5

Khan, A., Dubey, J. P., Su, C., Ajioka, J. W., Rosenthal, B. M., and Sibley, L. D. (2011). Genetic analyses of atypical Toxoplasma gondii strains reveal a fourth clonal lineage in North America. Int. J. Parasitol. 41, 645-655. doi: 10.1016/j. ijpara.2011.01.005S0020-7519(11)00046-4

Lair, S., Measures, L. N., and Martineau, D. (2016). Pathologic findings and trends in mortality in the beluga (Delphinapterus leucas) population of the St Lawrence 
estuary, Quebec, Canada, from 1983 to 2012. Vet. Pathol. 53, 22-36. doi: 10. $1177 / 03009858156047260300985815604726$

Lima, A. F. B., Gonçalves, L. R., and Queiroz, E. L. (2006a). Registro histórico de encalhe de uma baleia-de-bryde Balaenoptera edeni Anderson, 1879 (Mysticeti: Balaenopteridae), no rio Paraguaçu, baía de todos os santos, Bahia, Brasil [The historical record of a strading of a bryde's whale Balaenoptera edeni Anderson, 1879 (Mysticeti: Balaenopteridae), in the Paraguaçu river, todos os santos Bay, Bahia, Brazil]. Bioikos 20, 75-79.

Lima, A. F. B., Gonçalves, L. R., and Querioz, E. L. (2006b). The historical record of a stranding of a Bryde's whale Balaenoptera edeni Anderson, 1879 (Mysticeti: Balaenopteridae), in the paraguaçu river, todos os santos Bay, Bahia, Brazil. Biokos 20, 75-79.

Lindsay, D. S., and Dubey, J. P. (2009). Long-term survival of Toxoplasma gondii sporulated oocysts in seawater. J. Parasitol. 95, 1019-1020. doi: 10.1645/GE1919.1

Lodi, L., Tardin, R. H., Hetezel, B., Maciel, I. S., Figueiredo, L. D., and Simao, S. M. (2015). Bryde's whale (Cetartiodactyla:Balaenopteridae) occurrence and movements in coastal areas of southeastern Brazil. Zoologia 32, 171-175. doi: 10.1590/s1984-46702015000200009

Marino, A. M. F., Giunta, R. P., Salvaggio, A., Castello, A., Alfonzetti, T., Barbagallo, A., et al. (2019). Toxoplasma gondii in edible fishes captured in the Mediterranean basin. Zoonoses Public Hlth. 66, 826-834. doi: 10.1111/zph. 12630

Massie, G. N., Ware, M. W., Villegas, E. N., and Black, M. W. (2010). Uptake and transmission of Toxoplasma gondii oocysts by migratory, filter-feeding fish. Vet. Parasitol. 169, 296-303. doi: 10.1016/j.vetpar.2010.01.002S0304-4017(10) 00006-3

Mazzariol, S., Marcer, F., Mignone, W., Serracca, L., Goria, M., Marsili, L., et al. (2012). Dolphin Morbillivirus and Toxoplasma gondii coinfection in a Mediterranean fin whale (Balaenoptera physalus). BMC Vet. Res. 8:20. doi: 10.1186/1746-6148-8-201746-6148-8-20

Migaki, G., Sawa, T. R., and Dubey, J. P. (1990). Fatal disseminated toxoplasmosis in a spinner dolphin (Stenella longirostris). Vet. Pathol. 27, 463-464. doi: 10. 1177/030098589902700615

Mikaelian, I., Boisclair, J., Dubey, J. P., Kennedy, S., and Martineau, D. (2000). Toxoplasmosis in beluga whales (Delphinapterus leucas) from the St Lawrence estuary: two case reports and a serological survey. J. Comp. Pathol. 122, 73-76. doi: 10.1053/jcpa.1999.0341S0021997599903419

Miller, M. A., Gardner, I. A., Kreuder, C., Paradies, D. M., Worcester, K. R., Jessup, D. A., et al. (2002). Coastal freshwater runoff is a risk factor for Toxoplasma gondii infection of southern sea otters (Enhydra lutris nereis). Int. J. Parasitol. 32, 997-1006. doi: 10.1016/s0020-7519(02)00069-3

Miller, M. A., Grigg, M. E., Kreuder, C., James, E. R., Melli, A. C., Crosbie, P. R., et al. (2004). An unusual genotype of Toxoplasma gondii is common in California sea otters (i) and is a cause of mortality. Int. J. Parasitol. 34, 275-284. doi: 10.1016/j.ijpara.2003.12.008

Miller, M. A., Sverlow, K., Crosbie, P. R., Barr, B. C., Lowenstine, L. J., Gulland, F. M., et al. (2001). Isolation and characterization of two parasitic protozoa from a Pacific harbor seal (Phoca vitulina richardsi) with meningoencephalomyelitis. J. Parasitol. 87, 816-822. doi: 10.1645/0022-3395(2001)087[0816:iacotp] 2.0.co;2

Moura, J. F., and Siciliano, S. (2012). Stranding pattern of Bryde's whales along the southeastern coast of Brazil. Mar. Biodivers. Rec. 5:e73. doi: 10.1017/ S1755267212000528

Nicolle, C., and Manceaux, L. (1908). Sur une infection a corps de Leishman (ou organismes voisons) du gondi. C R Acad. Sci. 147:736.

Omata, Y., Umeshita, Y., Watarai, M., Tachibana, M., Sasaki, M., and Murata, K. (2006). Investigation for presence of Neospora caninum, Toxoplasma gondii and Brucella-species infection in killer whales (Orcinus orca) mass-stranded on the coast of Shiretoko, Hokkaido, Japan. J. Vet. Med. Sci. 68, 523-526. doi: $10.1292 /$ jvms.68.523

Pena, H. F., Gennari, S. M., Dubey, J. P., and Su, C. (2008). Population structure and mouse-virulence of Toxoplasma gondii in Brazil. Int. J. Parasitol. 38, 561-569. doi: 10.1016/j.ijpara.2007.09.004

Putignani, L., Mancinelli, L., Del Chierico, F., Menichella, D., Adlerstein, D., Angelici, M. C., et al. (2011). Investigation of Toxoplasma gondii presence in farmed shellfish by nested-PCR and real-time PCR fluorescent amplicon generation assay (FLAG). Exp. Parasitol. 127, 409-417. doi: 10.1016/j.exppara. 2010.09.007
Redlist of threatened species (2013). Available online at: www.iucnredlist.org/ (accessed May 10, 2019).

Reisfeld, L., Sacristán, C., Machado, E. F., Sánchez-Sarmiento, A. M., Costa-Silva, S., Ewbank, A. C., et al. (2019). Toxoplasmosis and Sarcocystis spp. infection in wild pinnipeds of the Brazilian coast. Dis. Aquat. Org. 136, 235-241. doi: 10.3354/dao03410

Resendes, A. R., Almeria, S., Dubey, J. P., Obon, E., Juan-Salles, C., Degollada, E., et al. (2002). Disseminated toxoplasmosis in a Mediterranean pregnant Risso's dolphin (Grampus griseus) with transplacental fetal infection. J. Parasitol. 88, 1029-1032. doi: 10.1645/0022-3395(2002)088[1029:dtiamp]2.0.co;2

Roe, W. D., Howe, L., Baker, E. J., Burrows, L., and Hunter, S. A. (2013). An atypical genotype of Toxoplasma gondii as a cause of mortality in Hector's dolphins (Cephalorhynchus hectori). Vet. Parasitol. 192, 67-74. doi: 10.1016/j. vetpar.2012.11.001

Shapiro, K., VanWormer, E., Aguilar, B., and Conrad, P. A. (2015). Surveillance for Toxoplasma gondii in California mussels (Mytilus californianus) reveals transmission of atypical genotypes from land to sea. Environ. Microbiol. 17, 4177-4188. doi: 10.1111/1462-2920.12685

Shapiro, K., VanWormer, E., Packham, A., Dodd, E., Conrad, P. A., and Miller, M. (2019). Type X strains of Toxoplasma gondii are virulent for southern sea otters (Enhydra lutris nereis) and present in felids from nearby watersheds. Proc. Biol. Sci. 286:20191334. doi: 10.1098/rspb.2019.1334

Shwab, E. K., Zhu, X. Q., Majumdar, D., Pena, H. F., Gennari, S. M., Dubey, J. P., et al. (2014). Geographical patterns of Toxoplasma gondii genetic diversity revealed by multilocus PCR-RFLP genotyping. Parasitology 141, 453-461. doi: 10.1017/S0031182013001844S0031182013001844

Sibley, L. D., Khan, A., Ajioka, J. W., and Rosenthal, B. M. (2009). Genetic diversity of Toxoplasma gondii in animals and humans. Philos. Trans. R. Soc. Lond. B Biol. Sci. 364, 2749-2761. doi: 10.1098/rstb.2009.0087364/1530/2749

Siciliano, S., Santos, M. C. O., Vicente, A. F. C., Avarenga, F. S., Zampirolli, E., Brito, J., et al. (2004). Strandings and feeding records of Bryde's whales (Balaenoptera edeni) in southeastern Brazil. J. Mar. Biol. Assoc. U.K. 84, 857-859. doi: 10.1017/ S0025315404010082h

Splendore, A. (1908). Un nuovo protozoa parassita de'conigli incontrato nelle lesioni anatomiche d'une malattia che ricorda in molti punti il Kala-azar dell'uomo. Nota preliminare pel. Rev. Soc. Sci. Sao Paulo 3, 109-112.

Su, C., Shwab, E. K., Zhou, P., Zhu, X. Q., and Dubey, J. P. (2010). Moving towards an integrated approach to molecular detection and identification of Toxoplasma gondii. Parasitology 137, 1-11. doi: 10.1017/s0031182009991065

Sundar, N., Cole, R. A., Thomas, N. J., Majumdar, D., Dubey, J. P., and Su, C. (2008). Genetic diversity among sea otter isolates of Toxoplasma gondii. Vet. Parasitol. 151, 125-132. doi: 10.1016/j.vetpar.2007.11.012

Van Bressem, M. F., Raga, J. A., Di Guardo, G., Jepson, P. D., Duignan, P. J., Siebert, U., et al. (2009). Emerging infectious diseases in cetaceans worldwide and the possible role of environmental stressors. Dis. Aquat. Organ. 86, 143-157. doi: 10.3354/dao02101

Van Wormer, E., Carpenter, T. E., Singh, P., Shapiro, K., Wallender, W. W., Conrad, P. A., et al. (2016). Coastal development and precipitation drive pathogen flow from land to sea: evidence from a Toxoplasma gondii and felid host system. Sci. Rep. 6:29252. doi: 10.1038/srep29252srep29252

Weir, C. R., MacLeod, C. D., and Pierce, G. J. (2012). Habitat preferences and evidence for niche partitioning amongst cetaceans in the waters between Gabon and Angola, eastern tropical Atlantic. J. Mar. Biol. Assoc. U.K. 92, 1735-1749. doi: $10.1017 /$ s0025315412000148

Wiseman, N., Stockin, K. A., and Scott-Baker, C. (2011). Seasonal occurrence and distribution of Bryde's whales in the Hauraki Gulf, New Zealand. Mar. Mamm. Sci. 27, E253-E267.

Conflict of Interest: The authors declare that the research was conducted in the absence of any commercial or financial relationships that could be construed as a potential conflict of interest.

Copyright (c) 2020 Díaz-Delgado, Groch, Ramos, Colosio, Alves, Pena and CatãoDias. This is an open-access article distributed under the terms of the Creative Commons Attribution License (CC BY). The use, distribution or reproduction in other forums is permitted, provided the original author(s) and the copyright owner(s) are credited and that the original publication in this journal is cited, in accordance with accepted academic practice. No use, distribution or reproduction is permitted which does not comply with these terms. 